\title{
An assessment of Malaysian wooden furniture manufacturers' readiness to embrace chain of custody (COC) certification
}

\begin{abstract}
Although Malaysia is a major producer and exporter of wood products in the world, the status of wood products certification in the industry is relatively unknown. Therefore, a study was carried out to assess the status of chain of custody certification among wooden furniture manufacturers using a structured questionnaire to interview firms who had participated at the annual Malaysian International Furniture Fair (MIFF). Results collated indicate that the readiness to adopt chain of custody certification among wooden furniture manufacturers was low. The lack of price premiums, limited market potential and high cost was cited as the primary reasons deterring furniture manufacturers from adopting chain of custody certification. Furthermore, the use of plantation wood resources, such as Rubberwood (Hevea brasiliensis), perceived to be certified wood resources, reflects the lack of understanding among the manufacturers. This study shows that an increasing adoption of chain of custody certification among wooden furniture manufacturers in Malaysia can be realized in the market organisation, especially with regards to price premiums and market requirements.
\end{abstract}

Keyword: Malaysian, wooden, furniture, manufacturers', chain of custody 